\title{
The efficiency of application of mineral fertilizers and microbiological preparations on legume-cereal meadow agrophytocenosis
}

\author{
Kurgak V. ${ }^{1}$, Karbivska Yu. ${ }^{2}$ \\ ${ }^{1} N S C$ «Institute of Agriculture of NAAS» \\ 2b Mashynobudivnykiv Str., Chabany, Kyiv-Sviatoshyn region, Kyiv oblast, Ukraine, 08162 \\ ${ }^{2}$ Vasyl Stefanyk Precarpathian National University \\ 57 Shevchenko Str., Ivano-Frankivsk, Ukraine, 76018

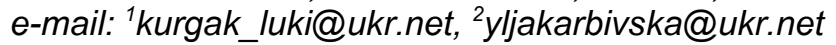

Goal. To determine peculiarities of the formation of seeded legume-cereal agrophytocenoses, their productivity and the chemical composition, nutritional value and energy content of the feed on the gray soils of the Carpathian region depending on mineral fertilizers and nitrogen-fixing preparations. Methods. Scientific - hypothesis, induction and deduction, analogy, generalization, and special - field, laboratory, mathematical-statistical, calculation. Results. They fixed the following: Lucerne was well kept in lucernecereal grass stand during the first 3 years, Red clover was well kept in clover-cereal grass stand only during the first 2 years of use with a share of both types of $41-69 \%$. Adding clover or lucerne to the mix of cereals in the variant without fertilizers on the background of N30P60K60 contributed: to the increase in the content of crude protein in dry weight on $4.2-4.4 \%$, to the security of fodder unit of digestible protein - on $30-38$ $\mathrm{g}$, as well as protein, digestibility of the dry weight of the feed in vitro, to the reduction of the content of crude fiber and nitrogen-free extractives. Conclusions. Using different types of legumes, in particular, clover or lucerne in the mixture of cereals increases the productivity of seeded herbage in the absence of fertilizer from 3.65 to $5.25-6.32$ t/ha of dry weight. More productive with the best chemical composition and nutritional value of feed is Lucerne-cereal seeded grass stand. At use of P90K120 in combination with nitrogen-fixing preparations the productivity of legume-cereal grass stand is increased by 12 and $19 \%$ in comparison with variant without fertilizers.

Key words: botanical composition, energy content, feed units, metabolizable energy, nutritive value, productivity, dry weight, chemical composition of the feed.

DOI: https://doi.org/10.31073/agrovisnyk202004-05

One of the most promising areas of intensification of onion growing in the world is the creation of sown grasslands with high legume content [1]. Partial replacement of mineral nitrogen with symbiotic is an important reserve for reducing energy consumption, which often accounts for half of its total costs on intensive grass cereals [2,3]. Increasing the use of legumes in onion growing is the most important part of the program for the introduction of energy-saving technologies abroad, including organic onion growing [4, 5].

Studies conducted in different geographical, climatic, edaphic conditions with different types of legumes, found that the inclusion of legumes in legumes-cereal cenoses without mineral nitrogen increases the productivity of meadows by $1.5-2.5$, and protein collection - 2-3 times compared to cereal grasses on the same background of the LCD [2, 3, 5-8]. In this case, the use of legumes in the composition of legumecereal stands replaces the introduction of grass grass $100-300 \mathrm{~kg} / \mathrm{ha}$ of mineral nitrogen.

The goal of the work. To establish the peculiarities of the formation of sown leguminous-cereal agrophytocenoses, their productivity and chemical composition, nutritional value and energy content of fodder on dark gray soils of Prykarpattia depending on mineral fertilizers and nitrogen-fixing preparations.

Materials and methods of research. Research to study the peculiarities of the formation of legumecereal meadow agrophytocenoses depending on fertilizers and nitrogen-fixing drugs was performed at the Precarpathian National University. Vasyl Stefanyk "during 2009-2011. The field experiment was based on dark gray podzolic surface gleyed with heavily loamy soil (Pidpechary village, Tysmenets district, IvanoFrankivsk region). Coverless sowing of mixtures of perennial grasses, according to the scheme of the experiment, was carried out in the spring of 2008.

The scheme of the two-factor experiment provides for seven levels of fertilizer in combination with the use of nitrogen-fixing drugs on alfalfa and clover-grass stands (Table 1. The size of sown areas $-18 \mathrm{~m}^{2}$, accounting $-25 \mathrm{~m}^{2}$. Repeat the experiment four times. and cereal grasses: meadow clover Anitra, alfalfa Cyanosis, red bonfire - Ira, boneless stalk - Mars, fenugreek - Horizon.

The use of grass stands is triangular. The first mowing was carried out in the phase of earing cereals budding-beginning of flowering legumes, otav - 30-35 days after the previous mowing.

Weather conditions during the three years of research were mainly favorable for the growth and formation of perennial grasses. The research was conducted according to generally accepted methods. The botanical composition of the studied grasses according to DSTU 8044: 2015 [9], productivity indicators per yield of 1 ha of dry mass, feed units, crude protein and metabolic energy - according to and DSTU 8044: 2015 [9], DSTU 8066: 2015 [10]. the first mass plant mass indices and chemical composition of feed digestibility in 
vitro - method of infrared spectroscopy, nutritious food and energy - by calculation by the ISO 4674: 2006 [11].

Mathematical processing of research results was performed by the method of analysis of variance according to Dospekhov BA [12].

Analysis of the botanical composition of grasslands formed on the basis of legume-cereal grass mixtures showed that in these environmental conditions, on average for the first three years of use, the share of legume components on all agrophones fluctuated between $35-61 \%$ (Table 1). The average share of alfalfa sown in alfalfa-grass stands was higher by $18-19 \%$ than the share of meadow clover in clover-grass stands with the same cereal components (red bonfire, boneless stalk, fenugreek).

With the application of nitrogen fertilizers at a dose of N30 on the background of the application of P60K60 there was a tendency to reduce the share of alfalfa in alfalfa-grass grassland. Meanwhile, the share of meadow clover in clover-grass grassland in this case did not change. 


\section{Productivity of legume-cereal grass mixtures with different fertilizers by years of use, $t / h a, 2009-2011$}

\begin{tabular}{|c|c|c|c|c|c|c|c|c|}
\hline \multirow{3}{*}{$\begin{array}{c}\text { Grass mixture (types of grasses } \\
\text { and sowing rates of their seeds, } \\
\mathrm{kg} / \mathrm{ha} \text { ) }\end{array}$} & \multirow{3}{*}{ Fertilizers } & \multirow{2}{*}{\multicolumn{3}{|c|}{ Dry mass by years }} & \multicolumn{4}{|c|}{ Average for 2009-2011dry } \\
\hline & & & & & \multirow{2}{*}{ weight } & \multirow{2}{*}{$\begin{array}{l}\text { of feed } \\
\text { unit }\end{array}$} & \multirow{2}{*}{$\begin{array}{l}\text { crude } \\
\text { protein }\end{array}$} & \multirow{2}{*}{$\begin{array}{l}\text { metabolic } \\
\text { energy, GJ/ha }\end{array}$} \\
\hline & & 2009 & 2010 & 2011 & & & & \\
\hline \multirow{7}{*}{$\begin{array}{l}\text { Meadow clover, } 10+\text { cereals } \\
\text { (boneless stalk, } 12+\text { multi-flowered } \\
\text { fenugreek, } 12+\text { red bonfire }, 10 \text { ) }\end{array}$} & Without fertilizers & 7,22 & 5,12 & 3,41 & 5,25 & 3,89 & 0,78 & 45,2 \\
\hline & $\mathrm{N}_{30} \mathrm{P}_{60} \mathrm{~K}_{60}$ & 7,73 & 5,63 & 3,93 & 5,76 & 4,32 & 0,90 & 50,1 \\
\hline & $\mathrm{N}_{30} \mathrm{P}_{60} \mathrm{~K}_{60}+$ strain & 8,05 & 5,93 & 4,10 & 6,03 & 4,58 & 0,95 & 53,1 \\
\hline & $\mathrm{P}_{60} \mathrm{~K}_{60}$ & 7,82 & 5,64 & 3,95 & 5,81 & 4,36 & 0,89 & 50,5 \\
\hline & $\mathrm{P}_{60} \mathrm{~K}_{60}+$ strain & 8,21 & 5,85 & 4,11 & 6,06 & 4,61 & 0,94 & 53,3 \\
\hline & $\mathrm{P}_{90} \mathrm{~K}_{120}$ & 8,13 & 5,86 & 4,12 & 6,04 & 4,53 & 0,93 & 52,5 \\
\hline & $\mathrm{P}_{90} \mathrm{~K}_{120}+$ strain & 8,43 & 6,01 & 4,32 & 6,25 & 4,75 & 0,98 & 55,0 \\
\hline \multirow{7}{*}{$\begin{array}{l}\text { Alfalfa for sowing }+ \text { the same } \\
\text { cereals }\end{array}$} & Without fertilizers & 6,92 & 6,61 & 5,43 & 6,32 & 4,80 & 1,04 & 55,6 \\
\hline & $\mathrm{N}_{30} \mathrm{P}_{60} \mathrm{~K}_{60}$ & 7,16 & 6,84 & 6,31 & 6,77 & 5,21 & 1,13 & 60,3 \\
\hline & $\mathrm{N}_{30} \mathrm{P}_{60} \mathrm{~K}_{60}+$ strain & 7,31 & 7,03 & 6,52 & 6,95 & 5,42 & 1,18 & 62,6 \\
\hline & $\mathrm{P}_{60} \mathrm{~K}_{60}$ & 7,15 & 7,16 & 6,50 & 6,94 & 5,34 & 1,15 & 61,8 \\
\hline & $\mathrm{P}_{60} \mathrm{~K}_{60}+$ strain & 7,22 & 7,33 & 6,81 & 7,12 & 5,55 & 1,19 & 64,1 \\
\hline & $\mathrm{P}_{90} \mathrm{~K}_{120}$ & 7,23 & 7,26 & 6,62 & 7,04 & 5,42 & 1,18 & 62,7 \\
\hline & $\mathrm{P}_{90} \mathrm{~K}_{120}+$ strain & 7,55 & 7,15 & 6,58 & 7,09 & 5,53 & 1,20 & 63,8 \\
\hline The same cereals & $\mathrm{N}_{30} \mathrm{P}_{60} \mathrm{~K}_{60}$ & 5,15 & 5,16 & 3,50 & 4,60 & 3,36 & 0,58 & 39,1 \\
\hline \multicolumn{9}{|c|}{$\mathrm{NIR}_{05}, \mathrm{t} / \mathrm{ha}$ by factors: } \\
\hline \multicolumn{2}{|c|}{ herbage } & 0,39 & 0,35 & 0,23 & 0,32 & & & \\
\hline \multicolumn{2}{|c|}{ fertilizer } & 0,27 & 0,25 & 0,24 & 0,25 & & & \\
\hline \multicolumn{9}{|c|}{ The share of factors, $\%$} \\
\hline \multicolumn{2}{|c|}{ herbage } & 61 & 58 & 54 & 58 & & & \\
\hline \multicolumn{2}{|c|}{ fertilizer } & 39 & 42 & 46 & 42 & & & \\
\hline
\end{tabular}


Increased the share of the bean component by a maximum of $6 \%$ when using $\mathrm{P}_{60} \mathrm{~K}_{60}$ on alfalfa-grass grass, while on clover-grass grass by a maximum of only $4 \%$.

More or less stably for three years on fertile dark gray soils alfalfa was kept in the grasslands, the share of which, regardless of fertilizer options in alfalfa-grass grasslands, ranged from 47 to $67 \%$ over the years. Over the years of grassland use, there was a tendency to a slight decrease in its share and, especially, for the introduction of $\mathrm{N}_{30} \mathrm{P}_{60} \mathrm{~K}_{60}$.

Meadow clover in clover-grass stands was well maintained only during the first two years of use in clovergrass stand with a share of 41 to $69 \%$. Although, already in the 2nd year of use compared to the 1 st year, its share was lower by $19-21 \%$. In the 3rd year it is practical fell out of the grass with a share of $4-5 \%$.

In these environmental conditions, on average, for the first three years of using a more influential factor on the productivity of phytocenoses at the rate of 1 ha of dry matter, there was a factor of grass cover with a share of $58 \%$ than the factor of fertilizer. Over the years in the direction from the 1st to the 3rd year of use, due to a decrease in the amount of bean component and a certain decrease in the action of symbiotic nitrogen, it decreased from 61 to $54 \%$. On the contrary, the influence of fertilizer factor has increased over the years from 39 to $46 \%$.

With the inclusion of different types of legumes, namely meadow clover, or alfalfa, in the mixture of cereals from stinging nettle, fenugreek and red fireweed, on average in 2009-2011, the productivity of sown grasses in the version without fertilizers increased from 3.65 up to 5.25-6.77 t/ha of dry weight, from 2.63 to 3.89-4.80 t/ha of feed units, from 0.38 to $0.78-1.04 \mathrm{t} / \mathrm{ha}$ of crude protein and from 31.0 to $45.2-55.6 \mathrm{GJ} / \mathrm{ha}$ of exchange energy or 1.4-2.7 times. Against the background of N30P60K60 application, the productivity of these leguminous-cereal herbaceous plants increased only 1.3-1.9 times in comparison with the cereal herbaceous grass, which indicates a decrease in the action of symbiotic legume nitrogen with nitrogen fertilizers. Therefore, a greater increase in productivity from the inclusion of legumes in cereals was in the version without fertilizers than in the version with the introduction of $\mathrm{N}_{30} \mathrm{P}_{60} \mathrm{~K}_{60}$.

Analysis of the results of research on fertilizer options showed that in both studied legumes-cereals the highest productivity per 1 ha of dry mass was obtained when applying P90K120 in combination with the use of nitrogen-fixing drugs, which is $12-19 \%$ more than the option without fertilizers. Their productivity from the application of $\mathrm{N}_{30} \mathrm{P}_{60} \mathrm{~K}_{60}$ compared to the option without fertilizers increased by $7-10 \%$. The application of these fertilizers was somewhat more effective on clover than on alfalfa-grass grass, which is due to a smaller share of the legume component. And the most effective application of N30P60K60 was on cereal grassland than on both studied legume-grass grasslands, when productivity increased by $26 \%$.

It was also effective to apply $\mathrm{P}_{60} \mathrm{~K}_{60}$ and $\mathrm{P}_{90} \mathrm{~K}_{120}$ to legumes, when the productivity of clover-grass grass increased by $11 \%$ and $15 \%$, respectively, and of alfalfa-grass by $10 \%$ and $11 \%$, respectively.

By including perennial legumes in the cereal mix, due to the action of symbiotic nitrogen, our studies improved feed quality by increasing crude protein content, protein and dry matter digestibility in vitro while reducing the content of nitrogen-free extractives, as well as crude fat and crude fiber. In particular, in the variants without fertilizers and against the background of application of N30P60K60 in comparison with cereal grassland in this case the content of crude protein in the dry weight of feed on average for three years of research increased from $10.4-12.5$ to $14.8-16.7 \%$ or $4.2-4.4$ absolute\% (Table 2). Among legumes and cereals, a significantly higher content in the dry mass of crude protein, regardless of fertilizer, was characterized by grass with the inclusion of alfalfa than meadow clover, due to better preservation and higher content of alfalfa.

Significantly less effect on the content of crude protein in the dry mass compared to the symbiotic nitrogen of perennial legumes in legumes and cereals had mineral nitrogen for its application to cereals in a dose of $\mathrm{N}_{30}$ in combination with the application of $\mathrm{P}_{60} \mathrm{~K}_{60}$, when its content increased from 10.4 to $12.5 \%$ or $2.1 \%$. Meanwhile, on legumes in this case, the crude protein content did not increase significantly. The introduction of different doses of phosphorus and potassium also increased its content insignificantly. The content of crude protein also increased insignificantly from the use of nitrogen-fixing strains on both studied legumes and cereals. 
2. The content of organic matter in the feed and digestibility of legume-cereal mixtures with different fertilizers, \% in dry weight, average for $2009-2011$

\begin{tabular}{|c|c|c|c|c|c|c|c|}
\hline $\begin{array}{l}\text { Grass mixture (types of grasses } \\
\text { and sowing rates of their seeds, } \\
\mathrm{kg} / \mathrm{ha} \text { ) }\end{array}$ & Fertilizers & Crude protein & Protein & $\begin{array}{l}\text { Crude } \\
\text { fat }\end{array}$ & $\begin{array}{c}\text { Cheese } \\
\text { fiber }\end{array}$ & BER & Digestibility \\
\hline \multirow{7}{*}{$\begin{array}{l}\text { Meadow clover, } 10+\text { cereals } \\
\text { (boneless stalk, } 12+\text { multi-flowered } \\
\text { fenugreek, } 12+\text { red bonfire, } 10 \text { ) }\end{array}$} & Without fertilizers & 14,8 & 10,4 & 3,3 & 26,4 & 46,2 & 58 \\
\hline & $\mathrm{N}_{30} \mathrm{P}_{60} \mathrm{~K}_{60}$ & 15,7 & 11,0 & 3,4 & 26,3 & 45,2 & 58 \\
\hline & $\mathrm{N}_{30} \mathrm{P}_{60} \mathrm{~K}_{60}+$ strain & 15,8 & 11,1 & 3,5 & 26,2 & 45,1 & 58 \\
\hline & $\mathrm{P}_{60} \mathrm{~K}_{60}$ & 15,3 & 10,7 & 3,4 & 25,7 & 46,2 & 58 \\
\hline & $\mathrm{P}_{60} \mathrm{~K}_{60}+$ strain & 15,5 & 10,9 & 3,5 & 25,6 & 46,0 & 58 \\
\hline & $\mathrm{P}_{90} \mathrm{~K}_{120}$ & 15,4 & 10,8 & 3,4 & 25,7 & 46,0 & 59 \\
\hline & $\mathrm{P}_{90} \mathrm{~K}_{120}+$ strain & 15,6 & 10,9 & 3,5 & 25,6 & 45,8 & 59 \\
\hline \multirow{7}{*}{$\begin{array}{l}\text { Alfalfa for sowing + the same } \\
\text { cereals }\end{array}$} & Without fertilizers & 16,5 & 11,6 & 3,2 & 25,7 & 45,5 & 56 \\
\hline & $\mathrm{N}_{30} \mathrm{P}_{60} \mathrm{~K}_{60}$ & 16,7 & 11,7 & 3,3 & 25,6 & 45,2 & 56 \\
\hline & $\mathrm{N}_{30} \mathrm{P}_{60} \mathrm{~K}_{60}+$ strain & 17,0 & 11,9 & 3,4 & 25,5 & 44,9 & 57 \\
\hline & $\mathrm{P}_{60} \mathrm{~K}_{60}$ & 16,6 & 11,6 & 3,3 & 25,8 & 45,1 & 57 \\
\hline & $\mathrm{P}_{60} \mathrm{~K}_{60}+$ strain & 16,8 & 11,8 & 3,4 & 25,7 & 44,9 & 57 \\
\hline & $\mathrm{P}_{90} \mathrm{~K}_{120}$ & 16,7 & 11,7 & 3,3 & 25,8 & 44,9 & 58 \\
\hline & $\mathrm{P}_{90} \mathrm{~K}_{120}+$ strain & 16,9 & 11,8 & 3,4 & 25,7 & 44,7 & 58 \\
\hline \multirow{2}{*}{ The same cereals } & Without fertilizers & 10,4 & 7,3 & 3,6 & 28,6 & 49,1 & 54 \\
\hline & $\mathrm{N}_{30} \mathrm{P}_{60} \mathrm{~K}_{60}$ & 12,5 & 8,8 & 3,7 & 29,0 & 46,5 & 55 \\
\hline \multicolumn{8}{|c|}{$\mathrm{NIR}_{05}, \mathrm{t} / \mathrm{ha}$ by factors: } \\
\hline \multirow{2}{*}{\multicolumn{2}{|c|}{$\begin{array}{l}\text { herbage } \\
\text { fertilizer }\end{array}$}} & 0,8 & 0,5 & 0,2 & 1,5 & 2,3 & 3 \\
\hline & & 0,9 & 0,6 & 0,2 & 1,6 & 2,4 & 3 \\
\hline \multicolumn{8}{|c|}{ The share of factors, $\%$} \\
\hline \multirow{2}{*}{\multicolumn{2}{|c|}{$\begin{array}{l}\text { herbage } \\
\text { fertilizer }\end{array}$}} & 60 & 59 & 58 & 59 & 57 & 61 \\
\hline & & 40 & 41 & 42 & 41 & 43 & 39 \\
\hline
\end{tabular}


A similar pattern is observed with the action of symbiotic and mineral nitrogen, but at a lower level with changes in the dry matter content of protein.

In legumes and cereals, the digestibility of dry feed in vitro increased by $2-4 \%$ compared to cereals on the same agrophones. The content of nitrogen-free extractives in the dry mass in this case decreased by 2.9$3.6 \%$, and crude fiber - by $2.2-2.9 \%$.

The content of nitrogen-free extractives in the dry weight of grass feed under the action of mineral nitrogen at a dose of $\mathrm{N} 30$ in combination with the introduction of P60K60 on cereal grass decreased by $2.6 \%$.

Indicators of the chemical composition of grass feed, in general, corresponded to the zootechnical standards of feeding cattle. However, the content of crude protein on sown cereals on the background without fertilizers and when applying N30P60K60 was lower than normal (10.4-10.8\% in dry weight at a rate of $14 \%$ ). When comparing the chemical composition of fodder legumes and grasses with standards (DSTU $4674,4684,4685,4782,8528$ ), the content of crude protein and crude fiber, for the manufacture of hay, haylage, silage, green fodder and artificially dried grass fodder was that the grass mainly meets the requirements of high-quality grass fodder. Cereal grass for application of N30P60K60 and without fertilizers in terms of crude protein and fiber content is suitable for the production of hay, haylage and green fodder of the 2nd class, and for the production of artificially dried grass fodder is completely unsuitable.

The inclusion of perennial legumes in the cereal mixture slightly improved the nutritional value of feed in terms of feed units and its energy intensity in terms of metabolic energy (Table 3). In this case, on average in 2009-2011, their content increased from 72-73 to 74-77 and from 8.5 to 8.6-9.0 MJ/kg, respectively. Under the influence of fertilizer, the parameters of nutrition and energy intensity changed little.

With the inclusion of perennial legumes as a source of symbiotic nitrogen in cereals, the supply of feed unit with digestible protein in the variant without good and against the background of N30P60K60 increased from 103-122 $\mathrm{g}$ to $141-152 \mathrm{~g}$ or 30-38 g. However, from the introduction of N30 P60K60 on cereal grass cover, this supply increased to a lesser extent (only by $19 \mathrm{~g}$ ) compared to the action of symbiotic nitrogen. Among legume-cereal grasslands, alfalfa-grass grassland was characterized by a slightly better supply of feed protein with digestible protein than clover-grass grassland.

\section{Nutrition, energy consumption of dry mass and provision of fodder unit with digestible protein of legume-cereal meadow grasses depending on the use of fertilizers and nitrogen-fixing preparations (average for 2009-2011)}

\begin{tabular}{|c|c|c|c|c|}
\hline $\begin{array}{l}\text { Grass mixture (types } \\
\text { of grasses and sowing } \\
\text { rates of their seeds, } \\
\mathrm{kg} / \mathrm{ha} \text { ) }\end{array}$ & Fertilizers & $\begin{array}{l}\text { Content } \\
\text { of feed } \\
\text { units, } \%\end{array}$ & $\begin{array}{l}\text { Content } \\
\text { of metabolic } \\
\text { energy, } \\
\mathrm{MJ} / \mathrm{kg}\end{array}$ & $\begin{array}{l}\text { Provision of feed } \\
\text { unit with digestible } \\
\text { protein, } g\end{array}$ \\
\hline \multirow{7}{*}{$\begin{array}{l}\quad \text { Meadow clover, } 10+ \\
\text { cereals (boneless stalk, } \\
12+\text { multi-flowered } \\
\text { fenugreek, } 12+\text { red } \\
\text { bonfire, } 10)\end{array}$} & Without fertilizers & 74 & 8,6 & 141 \\
\hline & $\mathrm{N}_{30} \mathrm{P}_{60} \mathrm{~K}_{60}$ & 75 & 8,7 & 146 \\
\hline & $\mathrm{N}_{30} \mathrm{P}_{60} \mathrm{~K}_{60}+$ strain & 76 & 8,8 & 146 \\
\hline & $\mathrm{P}_{60} \mathrm{~K}_{60}$ & 75 & 8,7 & 142 \\
\hline & $\mathrm{P}_{60} \mathrm{~K}_{60}+$ strain & 76 & 8,8 & 143 \\
\hline & $\mathrm{P}_{90} \mathrm{~K}_{120}$ & 75 & 8,7 & 143 \\
\hline & $\mathrm{P}_{90} \mathrm{~K}_{120}+$ strain & 76 & 8,8 & 145 \\
\hline \multirow{7}{*}{$\begin{array}{l}\text { Alfalfa for sowing + } \\
\text { the same cereals }\end{array}$} & Without fertilizers & 76 & 8,8 & 152 \\
\hline & $\mathrm{N}_{30} \mathrm{P}_{60} \mathrm{~K}_{60}$ & 77 & 8,9 & 151 \\
\hline & $\mathrm{N}_{30} \mathrm{P}_{60} \mathrm{~K}_{60}+$ strain & 78 & 9,0 & 153 \\
\hline & $\mathrm{P}_{60} \mathrm{~K}_{60}$ & 77 & 8,9 & 152 \\
\hline & $\mathrm{P}_{60} \mathrm{~K}_{60}+$ strain & 78 & 9,0 & 150 \\
\hline & $\mathrm{P}_{90} \mathrm{~K}_{120}$ & 77 & 8,9 & 153 \\
\hline & $\mathrm{P}_{90} \mathrm{~K}_{120}+$ strain & 78 & 9,0 & 152 \\
\hline \multirow{2}{*}{ The same cereals } & Without fertilizers & 72 & 8,5 & 103 \\
\hline & $\mathrm{N}_{30} \mathrm{P}_{60} \mathrm{~K}_{60}$ & 73 & 8,5 & 122 \\
\hline
\end{tabular}

The introduction of $\mathrm{N}_{30} \mathrm{P}_{60} \mathrm{~K}_{60}, \mathrm{P}_{60} \mathrm{~K}_{60} \mathrm{P}_{90} \mathrm{~K}_{120}$ and even against the background of these fertilizers strains of nitrogen-fixing drugs on the supply of feed unit digestible protein as well as the content of feed units and metabolic energy in the dry mass, mainly, naturally did not affect.

With the inclusion of perennial legumes in cereals, the mineral composition of the feed improved. In this case, the content of calcium in the dry mass increased from $0.42-0.44 \%$ to $0.53-0.56 \%$ or $0.11-0.12 \%$ and magnesium - from $0.12-0.13$ to $0,14-0.18 \%$ or $0.02-0.05 \%$, and potassium decreased from $2.59-2.62$ to $2.33-$ $2.38 \%$ or $0.24-0.26 \%$. 


\section{Conclusions}

During the formation of leguminous-cereal agrophytocenoses on dark gray soils of Prykarpattia, alfalfa sowing is stable during the first three years. meadow clover in clover-cereal - only during the first two years of use with a share of $41-69 \%$.

The inclusion of different types of legumes, namely meadow clover or alfalfa, to a mixture of cereals on average for the first 3 years increases the productivity of legumes and cereals agrophytocenoses in the form without fertilizers from 3.65 to 5.25-6.32 t/ha dry weight and from 0.38 to 0.78-1.04 t/ha of crude protein or 1.4-2.7 times. Alfalfa-cereal agrophytocenosis is more productive.

The highest productivity of legume-cereal agrophytocenoses is provided by the application of P90K120 in combination with the use of nitrogen-fixing drugs, increasing it by 12-19\% compared to the option without fertilizers.

The inclusion of meadow clover or alfalfa in the mixture of cereals improves the quality of fodder grasses. The content of crude protein in the dry weight increases from $10.4-12.5$ to $14.8-16.7 \%$ or $4.2-4.4 \%$, protein by $2.9 \%$, as well as the digestibility of the dry weight of feed in vitro by $2-4 \%$ of feed units - from $72-73$ to 74 $77 \%$, metabolic energy - from 8.5 to $8.6-9.0 \mathrm{MJ} / \mathrm{kg}$, and the supply of feed unit with digestible protein - from $103-122 \mathrm{~g}$ up to $141-152 \mathrm{~g}$ or $30-38 \mathrm{~g}$, calcium from $0.42-0.44 \%$ to $0.53-0.56 \%$ or $0.11-0.12 \%$ and magnesium from $0.12-0.13$ to $0.14-0.18 \%$ or $0.02-0.05 \%$ and reduces the content of crude fiber by $2.1-3.0 \%$ and nitrogen-free extractives - by 1.8-2.7\% and potassium from 2.59-2.62 to $2.33-2.38 \%$ or $0.24-0.26 \%$. The best chemical composition and nutrient content of the feed is characterized by a legume-cereal mixture with alfalfa sowing than meadow clover.

\section{References}

1. Hannaway, D. B., Brewer, L. J., Ates, S. et al. (2018). Ftatch clover: optimal selection of clover species. Sustainable meat and milk production from grasslands. Proceedings of the 27th General fteeting of the European Grassland Federation. (pp. 218-220). Cork, Ireland. June 17-21.

2. Petrichenko, V. F., \& Kurgak, V. G. (2013). Kulturni sinozhati ta pasovyshcha Ukrainy [Cultural hayfields and pastures of Ukraine]. Kyiv: Agrarian Science. [In Ukrainian].

3. Kurgak, V. G., \& Voloshin, V. M. (2017). Pidvyshchennia efektyvnosti vykorystannia bahatorichnykh bobovykh trav na lukakh Ukrainy. Posibnyk ukrainskoho khliboroba: nauk.-prakt. zb. [Improving the efficiency of perennial legumes in the meadows of Ukraine. Handbook of Ukrainian farmers "Biologization of agriculture": Scientific and practical collection]. (Vol. 1, pp. 288-291). Kyiv: Sigmatrade. [In Ukrainian].

4. Damborg, V. K., Stødkilde, L., Jensen, S. K., \& Weisbjerg, M. R. (4-8 September 2016). Characterization of protein and fiber in pulp after biorefining of red clover and perennial ryegrass. The multiple roles of grassland in the European bioeconomy. Proceedings of the 26th General Meeting of the European Grassland Federation. Trondheim, Norway. (pp. 366-371).

5. Peyraud, J. L., \& Peeters, A. (4-8 September 2016). The role of grassland based production system in the protein security. The multiple roles of grassland in the European bioeconomy. Proceedings of the 26th General Meeting of the European Grassland Federation. Trondheim, Norway. (pp. 29-43).

6. Nilsdotter-Linde, N., Halling, M. A., \& Jansson, J. (4-8 September 2016). Widening the harvest window with contrasting grass-clover mixtures. The multiple roles of grassland in the European bioeconomy. Proceedings of the 26th General Meeting of the European Grassland Federation. Trondheim, Norway. (pp. 191-193).

7. Voloshin, V. N. (2017). Botanicheskiy sostav i produktivnost lugovykh travostoev na serykh lesnykh pochvakh [Botanical composition and productivity of meadow grasslands on gray forest soils]. Bulletin of the Belarusian State Agricultural Academy. Gorki, 1, 62-66.

8. DSTU 8044:2015. Uhiddia pryrodni kormovi. Metody vyznachennia produktyvnosti (2018). [DSTU 8044: 2015. Natural forage lands. Methods for determining productivity]. Kyiv: "UkrNDNC". [In Ukrainian].

9. DSTU 8066:2015. Kormy dlia silskohospodarskykh tvaryn. Metody vyznachennia enerhoiemnosti i pozhyvnosti (2017). [DSTU 8066: 2015. Feed for farm animals. Methods for determining energy consumption and nutritional value]. Kyiv: "UkrNDNC". [In Ukrainian].

10. DSTU 4674:2006. Sino. Tekhnichni umovy (2008). [DSTU 4674: 2006. Hay. Specifications]. Kyiv: Derzhspozhivstandart. [In Ukrainian].

11. Dospekhov, B. A. (1979). Metodika polevogo opyta (s osnovami statisticheskoy obrabotki rezultatov issledovaniy) [Methods of field experience (with the basics of statistical processing of research results)]. Moscow: Kolos. [In Russian]. 